\title{
Funding for Primary Care (or Lack Thereof) and Community Health Centers: Impact of Title VII Training Programs
}

\author{
Jobn J. Frey III, MD, Associate Editor \\ Ann Fam Med 2008;6:562-563. DOI: 10.1370/afm.928.
}

$\mathrm{A}$ $\mathrm{n}$ article in the last issue of Annals explored the effect of Title VII training programs on community health center ( $\mathrm{CHC}$ ) staffing and participation in the National Health Service Corps. ${ }^{1}$ Ferrer makes suggestions for 3 different approaches to increasing the primary care workforce, 2 of which look at targeted funding for such training and a third that produces more overall doctors in CHCs. Some way other than Title VII—both in addition to or instead of —is worth modeling. A lift-all-boats model that increases production at all medical schools, not just those that are Title VII funded, would require, in Ferrer's words, "accepting students predisposed to social service, and should achieve better results." A 2\% increase in students who graduate in the United States and serve in CHCs would almost double other strategies based on Title VII targeting. ${ }^{2}$ Lopez similarly suggests broadening the base to move beyond CHCs into all communities. ${ }^{3}$

Of course, as Bowman outlines, doing that requires "common sense and leaders that stay in touch with each other and with the needs of most Americans, ${ }^{\prime \prime}$ which may not be a hallmark of US medical schools in 2008 .

Lesko $^{5}$ cites the American Association of Medical Colleges policy that "medical students and physicians should be free to determine for themselves...," which promotes the widely discredited notion that the market cures all things. Academic medicine seems determined to boldly go where we have been before. "Free to Be... You and Me" was a song from the 1970s about individuality and self-esteem. We need a new jingle if we are to figure what we, collectively and as a society, need. How about "Solidarity Forever"?

$\mathrm{O}^{\prime}$ Malley, ${ }^{6}$ whose work has identified the CHC workforce crisis, supports both the analysis by Rittenhouse et al and the prescription that increasing targeted support will help production and recruitment of doctors.

\begin{abstract}
Vinson $^{7}$ says, "send the [Rittenhouse] article to your senator." Who wouldn't agree? Good idea.
\end{abstract}

\section{THE CHINESE PHYSICIAN WORKFORCE IN COMMUNITIES}

In response to the article by Yang et al ${ }_{1}^{8}$ Kushner and Wang ${ }^{9}$ elaborate on the rapid changes that are being pursued for primary care in China and the challenges that still lie ahead. Bowman's commentary ${ }^{10}$ points out a number of aspects of primary care and the difficulties that are mirrored in both China and the United States: access, distribution of clinicians, education of a nonelite workforce, an aging population with chronic illness, and rural and urban disparities. These tensions lie in all societies that seek to find better care for everyone where economic and ethnic differences are strong.

\section{ALCOHOLISM IS A CHRONIC HEALTH PROBLEM}

Vinson $^{11}$ and Saxon ${ }^{12}$ both point out this obvious fact but both also point out the lack of serious attention by primary care clinicians to better screening, intervention, and prevention. Primary care reengineering is insisting on chronic disease registries for all practices, but has anyone seen a call for a registry of alcoholics or substance abuse patients? Probably not. But anyone in practice knows that these unregistered chronic illnesses are more problematic than anything else in a community. We can't work to improve something for which the dimensions of the problem are not known.

\section{OTHER VOICES}

A wide range of Annals articles ${ }^{13-17}$ generated important insights for primary care. Handzo ${ }^{18}$ raises "spiritual 
distress" as an important idea to address with the terminally ill. Would that be the "the long dark night of the soul" first used by John of the Cross?

Howard Stein, the anthropologist/poet from Oklahoma, reminds us that "through listening deeply to the other person and, at least temporarily suspending one's protocol, one often receives crucial answers to questions that one could not have known beforehand to ask." ${ }^{19}$

Clinician researcher Elizabeth Bayliss ${ }^{20}$ says, "I am becoming increasingly convinced that there is a role for providing patients individualized (non-MD) contact as part of the ongoing management of multiple conditions within primary care." Could and should some of those contacts be other patients in the community or in the practice?

The power of positive thinking - and acting - on cardiovascular disease mortality drew continuing comments from many and a response from the author ${ }^{21}$ in which he discusses what these study results might mean for the clinical process. Continue to take a positive perspective with patients, but, he cautions, "the more we learn about positive thinking and health, the more we need to look closely look at which policy/standardized elements of preventive medicine support this, which seek to overcome it, and what we should do about it"

Finally, Scott Murray, Professor of Primary Palliative Care, ${ }^{22}$ reaffirms that "an emotional bond between patient and professional, shared decision making, and continuity of care" are the anchors of healing in the care of terminally ill patients.

Please add your voice to the online discussion at http://www.AnnFamMed.org.

\section{References}

1. Rittenhouse DR, Fryer GE, Phillips RL, et al. Impact of Title VII training programs on community health center staffing and National Health Service Corps participation. Ann Fam Med. 2008;6(5):397-405.

2. Ferrer RL. Comparing strategies to care for the underserved [eletter]. http://www.annfammed.org/cgi/eletters/6/5/397\#10109, 25 Sep 2008.

3. Lopez CC. Need to expand the base [eletter]. http://www. annfammed.org/cgi/eletters/6/5/397\#9996, 10 Sep 2008.

4. Bowman RC. Integrating admission, training, and policy for health access results [eletter]. http://www.annfammed.org/cgi/ eletters/6/5/397\#10014, 11 Sep 2008.
5. Lesko SE. Comparison of Title VII and graduate medical education (GME) funding: the pauper and the prince [eletter]. http://www. annfammed.org/cgi/eletters/6/5/397\#10082, 19 Sep 2008.

6. O'Malley AS. Patients are coming, but who is going to take care of them [eletter]? http://www.annfammed.org/cgi/eletters/ 6/5/397\#10107, 22 Sep 2008.

7. Vinson DC. Contact congress [eletter]. http://www.annfammed.org/ cgi/eletters/6/5/397\#10069, 19 Sep 2008.

8. Yang J, Guo A, Wang Y, et al. Human resource staffing and service functions of community health services organizations in China. Ann Fam Med. 2008;6(5):421-427.

9. Kushner KK, Wang J. Interesting looking into workings of the community health service [eletter]. http://www.annfammed.org/cgi/ eletters/6/5/421\#10074, 19 Sep 2008.

10. Bowman RC. Health system designs in the US and China [eletter]. http://www.annfammed.org/cgi/eletters/6/5/421\#10005, 11 Sep 2008.

11. Vinson DC. We can do this [eletter]! http://www.annfammed.org/ cgi/eletters/6/5/435\#10071, 17 Sep 2008.

12. Saxon AJ. The great promise of medical management for alcohol dependence [eletter]. http://www.annfammed.org/cgi/eletters/ 6/5/435\#10018, 11 Sep 2008.

13. Daaleman TP, Usher BM, Williams SW, Rawlings J, Hanson LC. An exploratory study of spiritual care at the end of life. Ann Fam Med. 2008;6(5):406-411.

14. Sussman AL, Rivera M. 'Be gentle and sincere about it': a story about community-based primary care research. Ann Fam Med. 2008;6(5):463-465

15. Bogner HR, de Vries HF. Integration of depression and hypertension treatment: a pilot, randomized controlled trial. Ann Fam Med. 2008;6(5):295-301.

16. Gramling R, Klein W, Roberts M, Waring M, Gramling D, Eaton CB. Self-rated cardiovascular risk and 15-year cardiovascular mortality. Ann Fam Med. 2008;6(5):302-306.

17. Scott JG, Cohen DJ, DiCicco-Bloom B, Miller WL, Stange KC, Crabtree BF. Understanding healing relationships in primary care. Ann Fam Med. 2008;6(5):315-322.

18. Handzo GF. Spiritual distress as part of spiritual care [eletter]. http:// www.annfammed.org/cgi/eletters/6/5/406\#10076, 19 Sep 2008.

19. Stein HF. Good ppplied medical anthropology as good medicine [eletter]. http://www.annfammed.org/cgi/eletters/6/5/463\#10057, 15 Sep 2008

20. Bayliss EA. Integrated care is important for chronic illness [eletter] http://www.annfammed.org/cgi/eletters/6/4/295\#9782, 17 Aug 2008.

21. Gramling R. Self-rated risk, clinical communication and the selffulfilling prophecy [eletter]. http://www.annfammed.org/cgi/eletters/ 6/4/302\#9857, 24 Aug 2008.

22. Murray SA. Healing relationships are especially important for dying patients [eletter]. http://www.annfammed.org/cgi/eletters/ 6/4/315\#9684, 8 Aug 2008. 